\title{
The Effect of Amino Acid on the Uptake and Utilization of Tryptophan and other Precursors of Nicotinic Acid by Neurospora crassa
}

\author{
By RADHA K. PANICKER, E. R. B. SHANMUGASUNDARAM \\ AND U. S. ACHARYA \\ University Biochemical Laboratory, Madras 25, India
}

(Received 25 July 1961)

\begin{abstract}
SUMMARY
The influence of casein hydrolysate and certain amino acids on the uptake and utilization of tryptophan and other precursors of nicotinic acid biosynthesis by a mutant of Neurospora crassa which can grow on tryptophan or nicotinic acid was investigated. Whereas casein hydrolysate and certain amino acids inhibited the growth of the organism when tryptophan, kynurenine, or 3-hydroxykynurenine was present in the medium, they had no effect in the presence of other precursors, i.e. 3-hydroxyanthranilic acid or nicotinic acid. Studies have been made with wild strain and the mutant on the amount of tryptophan taken up from the medium at different periods of growth of the organism.
\end{abstract}

\section{INTRODUCTION}

One of the factors which seems to affect the conversion of tryptophan to nicotinic acid is the influence of certain proteins, when fed at concentrations with a tryptophan-low or nicotinic acid-free ration (Krehl, Sarma \& Elvehjem, 1946). This relationship between the 'level of dietary protein' and 'nicotinic acid requirement' was attributed to the various amino acids present in the protein and in turn to their influence on the digestive tract (Hanks, Henderson, Brickson \& Elvehjem, 1948). However, it was suggested by Rosen, Huff \& Perlzweig (1946) and Goryachenkova (1951) that the effect of the protein or the amino acids contained therein might result from an inhibition produced in the conversion of tryptophan to nicotinic acid, involving certain enzyme systems participating in the conversion. Mathieson $\&$ Catcheside (1955) in studies on histidine-requiring mutants of Neurospora crassa observed that some related amino acids inhibited the uptake of histidine. It was reported by Shanmugasundaram \& Sarma (1955) that certain protein hydrolysates when present in the medium inhibited the growth of a nicotinic acid-requiring mutant of $N$. crassa. In extending this observation, experiments have now been made to investigate the effect of casein hydrolysate, certain amino acids and $\mathbf{B}$ group vitamins on the uptake and utilization of tryptophan and its metabolites by a nicotinic acid-requiring mutant of $N$. crassa. 


\section{METHODS}

Organism and media. The strain (no. 5297 a) of Neurospora crassa and a mutant strain of it (no. 39401) kindly supplied by Dr H. K. Mitchell (California Institute of Technology, U.S.A.) were used in this work. The mutant strain is able to utilize tryptophan and other precursors for nicotinic acid synthesis shown below; the gene block is located before indole:

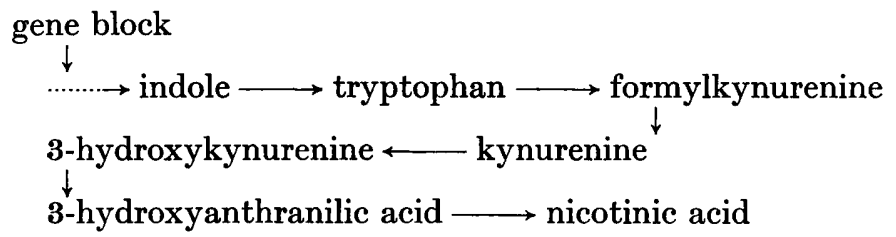

The organism was grown in Fries's medium as described by Horowitz \& Beadle (1943); it had the following composition (g./l.) ammonium tartrate, 5 ; ammonium nitrate, $1.0 ; \mathrm{K}_{2} \mathrm{HPO}_{4}, \mathbf{1} \cdot 0 ; \mathrm{MgSO}_{4} .7 \mathrm{H}_{2} \mathrm{O}, 0.5 ; \mathrm{NaCl}$ and $\mathrm{CaCl}_{2}, 0 \cdot 1$ (each); D-glucose, 20. The following trace elements $(\mathrm{mg} . / 1$.) were also incorporated: $\mathrm{B}, 0.01 ; \mathrm{Fe}, \mathbf{0 . 2}$; Mo, $0.02 ; \mathrm{Cu}, 0.1 ; \mathrm{Mn}, 0.02 ; \mathrm{Zn}, 2 \cdot 0$. In addition, biotin was added at $5 \mu \mathrm{g} . / 1$.

The $\mathrm{pH}$ value of the medium depended upon the tryptophan metabolite used. The medium was adjusted to $\mathrm{pH} 4.6$ in the case of nicotinic and 3-hydroxyanthranilic acids and to $\mathrm{pH} \mathrm{5.6}$ in the case of tryptophan, kynurenine and 3-hydroxykynurenine (Beadle \& Tatum, 1945). With 3-hydroxyanthranilic and nicotinic acids, the effects of casein hydrolysate and amino acids were tried only at the optimum for growth, namely $\mathrm{pH} 4 \cdot 6$ (Bonner \& Beadle, 1946), since they are less active at higher $\mathrm{pH}$ values, where dissociation becomes greater; at $\mathrm{pH} 5 \cdot 6$ the precursors become much less active and are not utilized quantitatively (Mitchell \& Nyc, 1948). Ten or $50 \mathrm{ml}$. of medium with necessary substrates were dispensed in $50 \mathrm{ml}$. or $250 \mathrm{ml}$. conical flasks, respectively, and sterilized at $121^{\circ}$ pressure for $15 \mathrm{~min}$. The inoculum was prepared by suspending in water washed spores from a 5-6 day slope, and adjusting the turbidity to about $80 \%$ transmission with a Lumetron photoelectric colorimeter model $400 \mathrm{~A}$. One or two drops of spore suspension containing $c .1 .5 \times 10^{8}$ spores $/ \mathrm{ml}$. were added per flask and incubation carried out at room temperature $\left(28\right.$ to $\left.30^{\circ}\right)$ for $72 \mathrm{hr}$. The mycelia were then collected, washed, partially dried between folds of filter paper and then dried to constant weight. The mycelia were then weighed in a Roller-Smith torsion balance.

Studies of the effect of casein hydrolysate on the uptake of tryptophan were done either by (i) directly inoculating spores into experimental media or (ii) transferring mycelium grown for $48 \mathrm{hr}$. in medium supplemented with tryptophan into experimental media.

Preparation of casein hydrolysate. The casein hydrolysate was prepared as described by Snell (1950) and the nitrogen was determined by the conventional micro-Kjeldahl method.

Estimation of tryptophan. Tryptophan was estimated colorimetrically with pdimethylaminobenzaldehyde (Spies \& Chambers, 1948) and (N-naphthyl)-ethylenediamine dihydrochloride (Eckert, 1943). 


\section{RESULTS}

The growth response of the mutant strain of Neurospora crassa (39401) to the various precursors of nicotinic acid was determined. The concentrations of the precursors for maximal growth are as follows ( $\mu \mathrm{g} . / 10 \mathrm{ml}$.). L-tryptophan, 200; DL-kynurenine sulphate, 120; DL-3-hydroxykynurenine, 80; 3-hydroxyanthranilic acid, 25 ; nicotinic acid, $7 \cdot 5$.

The influence of casein hydrolysate, pure amino acids and certain B group vitamins on the utilization of tryptophan, etc., was studied at a concentration of precursor at or slightly above the optimum concentration, so that any decrease in growth caused by the addition of test substance (casein hydrolysate or amino acid) would be due only to the effect of the test substances and not to a partial deficiency with respect to tryptophan or other precursor.

Casein hydrolysate inhibited the growth of the Neurospora crassa mutant 39401 when tryptophan, kynurenine, or 3-hydroxykynurenine was the precursor added to the medium (Fig. 1); it had no effect even at high concentrations with 3 -hydroxyanthranilic or nicotinic acids. Since casein hydrolysate is mostly a mixture of amino acids, the effects of individual amino acids were tested. Of twenty-one amino acids tested the following inhibited the growth of the mutant when tryptophan, kynurenine or 3-hydroxykynurenine were the precursors in the medium, namely: glycine, DL-alanine, $\beta$-alanine, L-cysteine, DL-threonine, DL-serine, DL-methionine, DL-valine, L-leucine, DL-isoleucine, DL- $\beta$-phenylalanine and $\mathrm{L}$-tyrosine. These amino acids had no effect with 3-hydroxyanthranilic acid or nicotinic acid. Casein hydrolysate had no effect on the growth of the wild strain, even when added at the high concentration of equiv. $1.0 \mathrm{mg}$. $\mathrm{N} / \mathrm{ml}$. medium.

Here therefore is a case where an amino acid inhibited the growth of a mutant requiring tryptophan. A similar observation was made by Mathieson \& Catcheside (1955) with a histidineless mutant of Neurospora crassa, where some amino acids (including L-arginine, DL-methionine, L-lysine, L-tryptophan, glycine, DL- $\beta$-phenylalanine, L-leucine, DL-valine, DL-isoleucine singly, and L-arginine $+\mathrm{L}$-lysine) inhibited the growth of their mutant. The growth inhibition was due to interference with uptake of histidine. However, Bonner \& Beadle (1946) showed that $N$. crassa mutant 39401 is a single gene mutant, with the genetic block placed before indole in the sequence of reactions leading to the formation of nicotinic acid from tryptophan. The enzymes and various factors affecting this biosynthetic pathway have been studied to some extent in other organisms. It appeared to be of interest to see whether the inhibition in growth by casein hydrolysate is due to inhibition of the tryptophan uptake or of the utilization of tryptophan in nicotinic acid biosynthesis.

To test whether the growth inhibition by casein hydrolysate was due to inhibition of tryptophan uptake, experiments were made on lines similar to those of Mathieson $\&$ Catcheside (1955). On the assumption that if inhibition of growth of the mutant by casein hydrolysate is because of interference with tryptophan uptake and not with its utilization, casein hydrolysate added to media inoculated with growing mycelia might be ineffective in preventing further growth, whereas it might prevent growth from a spore inoculum. The results of such experiments (Tables 1, 2, 3) with casein hydrolysate supplied alone and with tryptophan showed that casein hydrolysate inhibited the growth of the mycelia of the mutant (Tables 2, 3) 
suggesting that the influence of casein hydrolysate might not be solely on the uptake of tryptophan. However, examination of the results in Tables 2 and 3 shows that casein hydrolysate had at least two effects: (i) it inhibited growth at all concentrations tested during the first $24 \mathrm{hr}$. after the addition; (ii) then after a lag depending on concentration, it caused a considerable growth stimulation, which except at the highest concentration after $\mathbf{2 - 3}$ days more than made up for the initial inhibition.

Table 1. Influence of casein hydrolysate on the uptake of tryptophan; inoculation with spores of Neurospora crassa mutant 39401

The experimental mixtures were made up from $25 \mathrm{ml}$. lots of double strength medium (Fries) + supplement + water to $50 \mathrm{ml}$. final volume. Results are the averages of replicates.

\begin{tabular}{|c|c|c|c|c|}
\hline \multirow[b]{2}{*}{ Supplement to medium } & \multicolumn{3}{|c|}{$\begin{array}{l}\% \text { initial tryptophan remaining } \\
\text { in the medium at the end of }\end{array}$} & \multirow{2}{*}{$\begin{array}{c}\text { Weight } \\
\text { (mg. dry wt.) } \\
\text { of mycelium } \\
\text { after } 72 \mathrm{hr} \text {. } \\
\text { growth }\end{array}$} \\
\hline & $6 \mathrm{hr}$. & $24 \mathrm{hr}$. & $48 \mathrm{hr}$. & \\
\hline Nil (control) & 一 & - & 一 & - \\
\hline 1.25 mg. L-tryptophan & $82 \cdot 7$ & $54 \cdot 3$ & $40 \cdot 8$ & $28 \cdot 6$ \\
\hline $\begin{array}{l}\text { 1.25 mg. L-tryptophan }+ \\
\text { equiv. } 5 \mathrm{mg} . \mathrm{N} \text { of casein } \\
\text { hydrolysate }\end{array}$ & $91 \cdot 4$ & $54 \cdot 3$ & $32 \cdot 4$ & $110 \cdot 4$ \\
\hline $\begin{array}{l}1.25 \mathrm{mg} . \mathrm{L} \text {-tryptophan }+ \\
\text { equiv. } 6 \mathrm{mg} \text {. } \mathrm{N} \text { of casein } \\
\text { hydrolysate }\end{array}$ & $97 \cdot 2$ & $54 \cdot 3$ & $32 \cdot 4$ & $95 \cdot 0$ \\
\hline $\begin{array}{l}\text { 1.25 mg. L-tryptophan }+ \\
\text { equiv. } 7.5 \mathrm{mg} . \mathrm{N} \text { of casein } \\
\text { hydrolysate }\end{array}$ & $100 \cdot 0$ & $54 \cdot 1$ & $46 \cdot 4$ & $35 \cdot 4$ \\
\hline $\begin{array}{l}1.25 \mathrm{mg} . \text { L-tryptophan }+ \\
\text { equiv. } 8 \mathrm{mg} . \mathrm{N} \text { of casein } \\
\text { hydrolysate }\end{array}$ & $100 \cdot 0$ & $\mathbf{5 4} \cdot \mathbf{1}$ & $46 \cdot 4$ & $8 \cdot 0$ \\
\hline
\end{tabular}

Table 2. Effect of casein hydrolysate on uptake of tryptophan; inoculation with mycelium of wild strain of Neurospora crassa

The experimental mixtures were made up from $25 \mathrm{ml}$. lots of double strength medium (Fries) + supplement + water to final volume $50 \mathrm{ml}$. Weight of mycelia as inoculum: $\mathbf{7 0} 8 \mathrm{mg}$. Results are the averages of replicates.

\begin{tabular}{|c|c|c|c|c|c|c|}
\hline \multirow[b]{2}{*}{ Supplement to medium } & \multicolumn{3}{|c|}{$\begin{array}{l}\% \text { initial tryptophan } \\
\text { remaining in culture } \\
\text { filtrate at the end of }\end{array}$} & \multicolumn{3}{|c|}{$\begin{array}{l}\text { Weight (mg. dry wt.) of } \\
\text { mycelium at the end of }\end{array}$} \\
\hline & $24 \mathrm{hr}$. & $48 \mathrm{hr}$. & $72 \mathrm{hr}$. & $24 \mathrm{hr}$. & $48 \mathrm{hr}$. & $72 \mathrm{hr}$. \\
\hline Nil & $\mathbf{0}$ & 8 & 8 & $110 \cdot 4$ & $174 \cdot 6$ & $194 \cdot 6$ \\
\hline 1.25 mg. L-tryptophan & $66 \cdot 6$ & $55 \cdot 0$ & $42 \cdot 5$ & $108 \cdot 8$ & $140 \cdot 0$ & $150 \cdot 8$ \\
\hline $\begin{array}{l}1.25 \mathrm{mg} \text {. L-tryptophan }+ \\
\text { equiv. } 5 \mathrm{mg} . \mathrm{N} \text { of } \\
\text { casein hydrolysate }\end{array}$ & $66 \cdot 6$ & $\mathbf{3 7 \cdot 5}$ & $\mathbf{2 2 \cdot 5}$ & $127 \cdot 8$ & $178 \cdot 8$ & $256 \cdot 4$ \\
\hline $\begin{array}{l}\text { 1.25 mg. L-tryptophan }+ \\
\text { equiv. } 7 \mathrm{mg} . \mathrm{N} \text { of } \\
\text { casein hydrolysate }\end{array}$ & $85 \cdot 0$ & $37 \cdot 5$ & $20 \cdot 8$ & $114 \cdot 8$ & $161 \cdot 8$ & $220 \cdot 8$ \\
\hline $\begin{array}{l}1.25 \text { mg. L-tryptophan }+ \\
\text { equiv. } 10 \mathrm{mg} . \mathrm{N} \text { of } \\
\text { casein hydrolysate }\end{array}$ & $90 \cdot 0$ & $62 \cdot 5$ & $32 \cdot 5$ & $130 \cdot 0$ & $164 \cdot 6$ & $216 \cdot 8$ \\
\hline
\end{tabular}


Table 3. Effect of casein hydrolysate on uptake of tryptophan by growing mycelia of mutant strain of Neurospora crassa (39401)

The experimental mixtures were made up from $25 \mathrm{ml}$. lots of double strength medium (Fries) + supplement + water to $50 \mathrm{ml}$. Results represent averages of replicates.

\begin{tabular}{|c|c|c|c|c|c|c|}
\hline \multirow[b]{2}{*}{ Supplement to medium } & \multicolumn{3}{|c|}{$\begin{array}{l}\% \text { initial tryptophan } \\
\text { remaining in culture filtrate } \\
\text { at the end of }\end{array}$} & \multicolumn{3}{|c|}{$\begin{array}{l}\text { Weight (mg. dry wt.) of } \\
\text { mycelium at the end of }\end{array}$} \\
\hline & $24 \mathrm{hr}$. & $48 \mathrm{hr}$. & $72 \mathrm{hr}$. & $24 \mathrm{hr}$. & $48 \mathrm{hr}$. & $72 \mathrm{hr}$. \\
\hline Nil (control) & - & 一 & 一 & $5 \cdot 6$ & $10 \cdot 0$ & $14 \cdot 6$ \\
\hline 1.25 mg. L-tryptophan & $78 \cdot 3$ & $52 \cdot 2$ & $34 \cdot 7$ & $16 \cdot 2$ & $43 \cdot 0$ & $59 \cdot 0$ \\
\hline $\begin{array}{l}\text { Equiv. } 5.0 \mathrm{mg} . \mathrm{N} \text { of } \\
\text { casein hydrolysate }\end{array}$ & - & - & - & $5 \cdot 6$ & $7 \cdot 8$ & $10 \cdot 4$ \\
\hline $\begin{array}{l}1.25 \mathrm{mg} . \text { L-tryptophan }+ \\
5 \mathrm{mg} . \mathrm{N} \text { of casein } \\
\text { hydrolysate }\end{array}$ & $95 \cdot 6$ & $56 \cdot 5$ & $21 \cdot 8$ & $8 \cdot 0$ & $64 \cdot 0$ & $94 \cdot 6$ \\
\hline $\begin{array}{l}8 \mathrm{mg} . \mathrm{N} \text { of casein } \\
\text { hydrolysate }\end{array}$ & - & 一 & - & $4 \cdot 2$ & $3 \cdot 8$ & $7 \cdot 0$ \\
\hline $\begin{array}{l}1.25 \mathrm{mg} \text {. L-tryptophan }+ \\
7 \mathrm{mg} \text {. N of casein } \\
\text { hydrolysate }\end{array}$ & $100 \cdot 0$ & $60 \cdot 9$ & $43 \cdot 5$ & $8 \cdot 6$ & $55 \cdot 6$ & $94 \cdot 8$ \\
\hline $\begin{array}{l}10 \mathrm{mg} . \mathrm{N} \text { of casein } \\
\text { hydrolysate }\end{array}$ & - & 一 & - & $4 \cdot 0$ & $3 \cdot 8$ & $7 \cdot 8$ \\
\hline $\begin{array}{l}1.25 \mathrm{mg} . \mathrm{L} \text {-tryptophan }+ \\
10 \mathrm{mg} . \mathrm{N} \text { of casein } \\
\text { hydrolysate }\end{array}$ & $100 \cdot 0$ & $69 \cdot 6$ & $4,1 \cdot 3$ & $7 \cdot 4$ & $14 \cdot 2$ & $13 \cdot 0$ \\
\hline
\end{tabular}

Table 4. Influence of certain group $B$ vitamins alone and in the presence of casein hydrolysate on the utilization of tryptophan, kynurenine and 3-hydroxykynurenine by Neurospora crassa mutant (39401)

In all experiments to $5 \mathrm{ml}$. double strength concentrated medium (Fries), the supplements were added in solution and the final volume was adjusted to $10 \mathrm{ml}$. before autoclaving. The mycelia were removed after growth for $72 \mathrm{hr}$. Results represent averages of replicates.

\begin{tabular}{|c|c|c|c|c|c|c|}
\hline & & & Meta & bolite & & \\
\hline & $250 \mu$ g. L-t & $\begin{array}{l}\text { ryptophan/ } \\
\text { ssk }\end{array}$ & $\begin{array}{r}120 \mu \mathrm{g} . \mathrm{DL} \\
\text { sulpha }\end{array}$ & $\begin{array}{l}\text { kynurenine } \\
\text { te/flask }\end{array}$ & $\begin{array}{r}75 \mu \text { g. DL- } \\
\text { kynuren }\end{array}$ & $\begin{array}{l}\text { 3-hydroxy } \\
\text { ine/flask }\end{array}$ \\
\hline B-group vitamin added & $\begin{array}{c}\text { Without } \\
\text { casein } \\
\text { hydrolysate }\end{array}$ & $\begin{array}{r}\text { With casein } \\
\text { hydrolysate } \\
\text { equiv. } \\
1.5 \text { mg. N } \\
\text { My }\end{array}$ & $\begin{array}{l}\text { Without } \\
\text { casein } \\
\text { hydrolysate } \\
\text { elium harves }\end{array}$ & $\begin{array}{l}\text { With casein } \\
\text { hydrolysate } \\
\text { equiv. } \\
3.75 \mathrm{mg} . \mathrm{N} \\
\text { ted (mg. dry }\end{array}$ & $\begin{array}{l}\text { Without } \\
\text { casein } \\
\text { hydrolysate } \\
\text { wt.) }\end{array}$ & $\begin{array}{r}\text { With cas } \\
\text { hydrolys } \\
\text { equiv. } \\
1.5 \mathrm{mg} .\end{array}$ \\
\hline Control & $24 \cdot 1$ & $14 \cdot 1$ & $\mathbf{2 8} \cdot 2$ & $12 \cdot 1$ & $27 \cdot 0$ & $13 \cdot 9$ \\
\hline Thiamine (1 mg.) & $23 \cdot 2$ & $25 \cdot 7$ & $28 \cdot 4$ & $40 \cdot 8$ & $27 \cdot 4$ & $20 \cdot 1$ \\
\hline Riboflavin (1 mg.) & $14 \cdot 2$ & $8 \cdot 1$ & $27 \cdot 8$ & $16 \cdot 0$ & $26 \cdot 3$ & $13 \cdot 4$ \\
\hline Pyroxidine (1 mg.) & $23 \cdot 0$ & $26 \cdot 2$ & $28 \cdot 3$ & $18 \cdot 6$ & $26 \cdot 5$ & $14 \cdot 1$ \\
\hline $\begin{array}{l}p \text {-amino-benzoic acid } \\
\text { (1 mg.) }\end{array}$ & $25 \cdot 2$ & $15 \cdot 1$ & $27 \cdot 9$ & $14 \cdot 8$ & $27 \cdot 4$ & $13 \cdot 5$ \\
\hline Folic acid (1 mg.) & $25 \cdot 0$ & $27 \cdot 1$ & $27 \cdot 6$ & 一 & $26 \cdot 3$ & - \\
\hline $\begin{array}{l}\text { Calcium pantothenate } \\
\text { (1 mg.) }\end{array}$ & $25 \cdot 2$ & $14 \cdot 4$ & $28 \cdot 2$ & $15 \cdot 1$ & $27 \cdot 9$ & $13 \cdot 1$ \\
\hline Choline (2 mg.) & $25 \cdot 4$ & $26 \cdot 0$ & $28 \cdot 0$ & $43 \cdot 7$ & $27 \cdot 1$ & $21 \cdot 5$ \\
\hline Inositol (1 mg.) & $25 \cdot 0$ & $13 \cdot 8$ & $28 \cdot 5$ & $15 \cdot 5$ & $27 \cdot 1$ & $13 \cdot 6$ \\
\hline Vitamin B $12(2 \mu \mathrm{g})$. & $24 \cdot 6$ & $13 \cdot 6$ & $27 \cdot 9$ & $16 \cdot 1$ & $27 \cdot 3$ & $13 \cdot 3$ \\
\hline
\end{tabular}




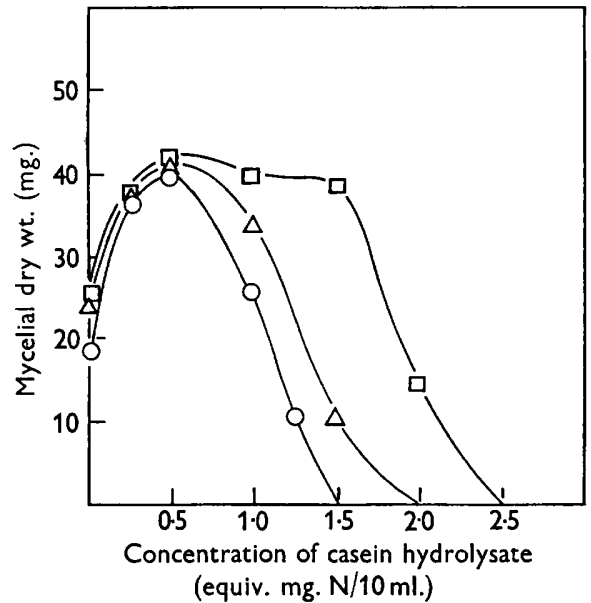

Fig. 1

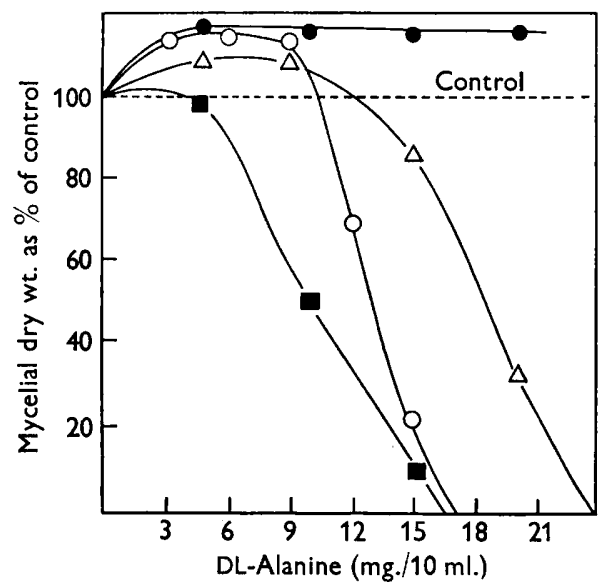

Fig. 3

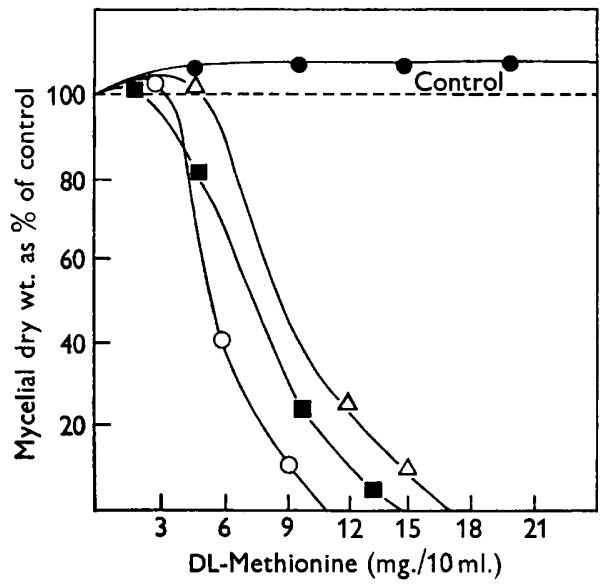

Fig. 5

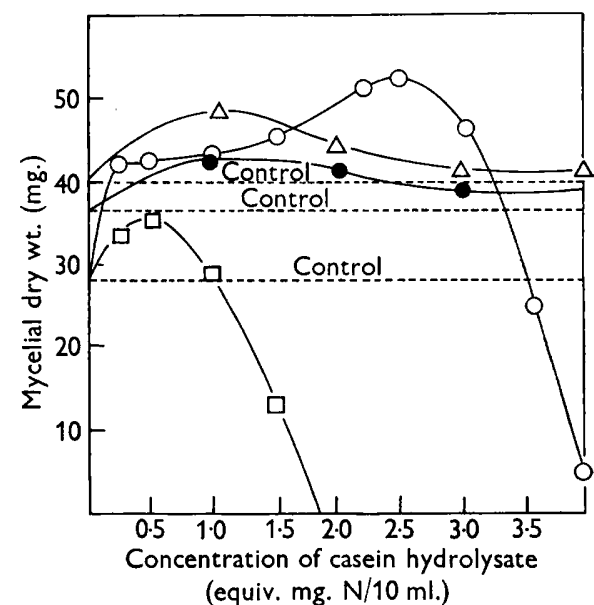

Fig. 2

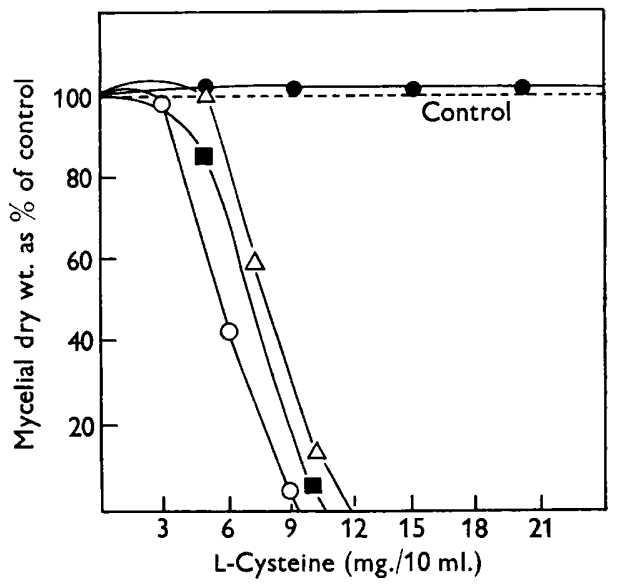

Fig. 4

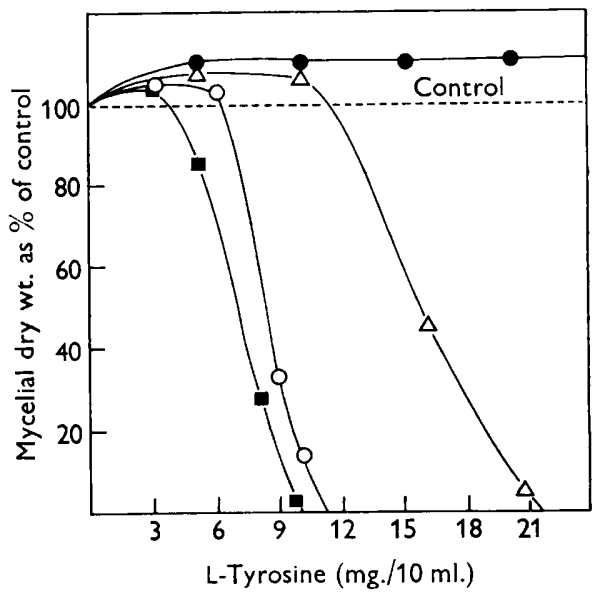

Fig. 6

For legends see foot of facing page. 
The initial inhibition seems to be associated with an almost complete inhibition of tryptophan uptake.

Growth stimulation by casein hydrolysate or certain amino acids at lower concentrations can be seen in Figs. 1-6. However, at higher concentrations, growth was inhibited. As the concentration of tryptophan in the medium was increased, greater amounts of casein hydrolysate or amino acid were needed to produce inhibition of growth. This suggests the possibility of the existence of a competition between the amino acids in casein hydrolysate and tryptophan or its metabolites either for uptake or for enzymes normally involved in tryptophan metabolism after uptake. That casein hydrolysate and certain amino acids inhibited the activity of the enzyme, kynureninase in tryptophan metabolism was observed in rats by Goryachenkova (1951) and in Neurospora crassa by Jakoby \& Bonner (1953). The inhibitory amino acids formed in the present work are more or less the same as those observed in the enzymic studies just mentioned, suggesting that the influence of casein hydrolysate and amino acids may be to some extent on the utilization of tryptophan.

The inhibitory amino acids are mono-amino mono-carboxylic acids containing an alanine side chain and the inhibited metabolites too (tryptophan, kynurenine, 3-hydroxykynurenine) have alanine side chains. This suggests an inhibitory function of the amino acids by competition involving the alanine moiety of the three metabolites. This seems to be supported by the absence of inhibition when the organism is supplied with other metabolites, namely 3-hydroxyanthranilic acid and nicotinic acid, where no alanine side chain is present.

Another possible effect of casein hydrolysate may be that it may produce in the Neurospora crassa some B group vitamin-requirement; it is known that some vitamins are involved in the conversion of tryptophan to nicotinic acid (Dalgleish, 1951). From Table 4 it can be seen that the inhibition produced by casein hydrolysate in the case of the metabolite tryptophan was annulled by thiamine, pyridoxine, folic acid or choline whereas kynurenine inhibition was annulled by thiamine or choline. Thiamine and choline decreased the inhibition with 3-hydroxykynurenine as metabolite. These vitamins do not have any effect when added alone and are normally synthesized by the organism.

Fig. 1. Influence of casein hydrolysate on the growth of Neurospora crassa mutant 39401 with tryptophan as nicotinic acid precursor.

Each flask contained $5 \mathrm{ml}$. double strength medium (Fries) with tryptophan and casein hydrolysate at various concentrations; final volume $10 \mathrm{ml}$. L-tryptophan $200 \mathrm{mg}$., O-O; L-tryptophan 250 mg., $\triangle-\triangle$; L-tryptophan 300 mg., $\square-\square$.

Fig. 2. Influence of casein hydrolysate on the growth of Neurospora crassa mutant 39401 with tryptophan metabolites in the medium.

Each flask contained $5 \mathrm{ml}$. double strength medium, with the metabolites added for maximal growth and casein hydrolysate at various concentrations; final volume $10 \mathrm{ml}$. DL-kynurenine sulphate, $\mathrm{O}-\mathrm{O}$; D-3-hydroxyanthranilic acid, $\triangle-\triangle$; DL-3-hydroxykynurenine, $\square-\square$; Nicotinic acid, -0.

Figs. 3-6. Influence of certain amino acids on the growth of Neurospora crassa mutant 39401 with tryptophan or other nicotinic acid precursors.

Each flask contained $5 \mathrm{ml}$. double strength basal medium with precursor added for maximal growth and the amino acid added at various concentrations as solution in water; final volume of $10 \mathrm{ml}$. L-tryptophan, $\bigcirc-O$; DL-kynurenine sulphate, $\Delta-\Delta$; 3-hydroxykynurenine, - - ; nicotinic acid, -0. Observations for 3-hydroxyanthranilic acid are almost the same as for nicotinic acid and hence not presented in the Figures. 
Our thanks are due to Dr C. P. Berg, Dr B. S. Schweigert and Professor A. Butenandt for the generous gift of tryptophan metabolites and to the University Grants Commission (India) for the award of a pre-doctoral merit scholarship to Miss R. Panicker. Some of the results presented herein were incorporated in an M.Sc. thesis submitted to the University of Madras by U. S. Acharya.

\section{REFERENCES}

Beadue, G. W. \& Tatum, E. L. (1945). Methods of producing and detecting mutations concerned with nutritional requirements. Amer. J. Bot. 32, 678.

Bonner, D. M. \& Beadle, G. W. (1946). Mutant strains of Neurospora requiring nicotinamide or related compounds for growth. Arch. Biochem. 11, 319.

Dalgleish, C. E. (1951). Tryptophan metabolism. Quart. Rev. chem. Soc. 5, 227.

ECKERT, H. W. (1943). A new micro-colorimetric method for the determination of tryptophan. J. biol. Chem. 148, 205.

Goryachenkova, E. V. (1951). Blocking of kynureninase action by amino acids and its significance in pathogenesis of pellagra. Dokl. Akad. Nauk. SSSR, 80, 643.

Hanks, L. V., Henderson, L. M., Brickson, W. L. \& ElvehJem, C. A. (1948). Effect of amino acids on the growth of rats on niacin tryptophan deficient rations. J. biol. Chem. $174,873$.

Horowitz, N. H. \& Beadle, G. W. (1943). A microbiological method of determination of choline by use of mutant of Neurospora crassa. J. biol. Chem. 150, 325.

JACKoBY, W. B. \& BonNer, D. M. (1953). Kynureninase from Neurospora crassa. Interaction of enzyme with substrate, co-enzyme and amines. J. biol. Chem, 205, 709 .

Krehl, W. A., SARMa, P. S. \& ElvehJem, C. A. (1946). The effect of protein on the nicotinic acid and tryptophan requirement of the growing rat. J. biol. Chem. 162, 403.

Mathieson, M. J. \& Catcheside, D. G. (1955). Inhibition of histidine uptake in Neurospora crassa. J. gen. Microbiol. 13, 72.

MrtcheLl, H. K. \& NYC, J. F. (1948). Hydroxyanthranilic acid as a precursor of nicotinic acid in Neurospora crassa. Proc. nat. Acad. Sci., Wash. 34, 1.

Rosen, F., Huff, J. W. \& Perlzweig, W. A. (1946). Effect of tryptophan on the synthesis of nicotinic acid in the rat. J. biol. Chem. $163,343$.

Shanmugasundaram, E. R. B. \& Sarma, P. S. (1955). Interrelationship among vitamins and amino acids. Part IV. Influence of protein hydrolysates on the biological synthesis of nicotinic acid from tryptophan in Neurospora crassa. J. sci. industr. Res. 14C, 105.

SNELL, E. E. (1950). Vitamin Methods, p. 364. Ed. by P. György. New York: Academic Press.

Spies, J. R. \& Chambers, D. C. (1948). Chemical determination of tryptophan. Analyt. Chem. 20, 30. 